\title{
Extrusion of benzoic acid in Saccharomyces cerevisiae by an energy-dependent mechanism
}

\author{
Marília Henriques, Célia Quintas† and Maria C. Loureiro-Dias \\ Author for correspondence: Maria C. Loureiro-Dias. Tel: +351 14431344 . Fax: + 35114431631. \\ e-mail: mcdias@pen.gulbenkian.pt
}

Laboratory of Microbiology, Gulbenkian Institute of Science, Ap. 14, 2781 Oeiras Codex, Portugal

\begin{abstract}
When grown in the presence of benzoic acid, Saccharomyces cerevisiae was able to extrude $\left[{ }^{14} \mathrm{C}\right.$ benzoic acid when a pulse of glucose was given to preloaded cells. While octanoic, sorbic, hexanoic, salicylic, butyric and propionic acids were also inducers, ethanol and acetic acid were not. The mechanism of extrusion required energy and prior growth in the presence of the inducers. Diethylstilbestrol, an inhibitor of ATPases, prevented benzoic acid extrusion. Propionic acid was not actively extruded in cells adapted to either benzoic or propionic acid, behaving as an appropriate probe to measure intracellular pH. Even though the extrusion mechanism was active, benzoic acid entered the cells by a simple diffusion mechanism.
\end{abstract}

Keywords: Saccharomyces cerevisiae, weak acids stress, extrusion, benzoic acid

\section{INTRODUCTION}

Benzoic acid, like other lipophilic weak acids, has been used as a food preservative which, under acidic conditions, diffuses into the cytoplasm of micro-organisms, where dissociation occurs. This results in an accumulation of the anion and a drop of the intracellular $\mathrm{pH}$. This phenomenon has been well-established and it constitutes the basis of the methodology to evaluate intracellular $\mathrm{pH}$ utilizing weak acids as probes (Rottenberg, 1979).

Intracellular acidification has been shown to inhibit metabolic activities during glycolysis in Saccharomyces cerevisiae (Krebs et al., 1983; Pampulha \& LoureiroDias, 1990), resulting in the accumulation of hexose monophosphates and depletion of ATP (Krebs et al., 1983). To overcome this deleterious situation and underlying the inhibitory effects of weak acids on microbial performance, intracellular acidification has been suggested to provoke a diversion of ATP from anabolic processes to maintenance purposes, resulting in a decrease in the yield of biomass as for the energy source (Verduyn et al., 1992; Warth, 1988). The main explanation for this behaviour has been the consumption of ATP by the $\mathrm{H}^{+}$-pumping ATPase, restoring the intracellular $\mathrm{pH}$ to physiological values. It was also considered that in $S$. cerevisiae the anion might also be pumped out of the cell (Verduyn et al., 1992), by comparing measured extracellular concentrations of

†Present address: Escola Superior de Tecnologia, Universidade do Algarve, Campus da Penha, 8000 Faro, Portugal. benzoic acid with those expected if equilibrium had been reached across the plasma membrane. It was concluded that the intracellular concentration of benzoic acid was lower than expected. This observation suggests that a mechanism was present that was responsible for the expulsion of benzoic acid. A mechanism with similar functions had been assigned in Zygosaccharomyces bailii (Warth, 1977). This species is particularly resistant to weak acids, representing the most dangerous of spoilage yeasts (Thomas \& Davenport, 1985). Warth (1977) presented some evidence that $Z$. bailii, but not $S$. cerevisiae, could extrude benzoic acid, and this was considered one of the mechanisms of resistance to preservatives in Z. bailii. More recently, Cole \& Keenan (1987), studying the effect of weak acids and external $\mathrm{pH}$ on the intracellular $\mathrm{pH}$ of $Z$. bailii, suggested that the loss of benzoic acid observed after the addition of a pulse of sugar to a suspension of starved cells could be attributed to changes in intracellular $\mathrm{pH}$.

Evidence has been presented that some gene products involved in pleiotropic drug resistance will expel drugs; e.g. the sequence of the PDR5 gene indicates that the product is a membrane protein with an ATP-binding cassette (Decottignies et al., 1994). Whether of this type, or belonging to the major facilitator superfamily, a number of gene products probably involved in the extrusion of drugs have been identified (Balzi \& Goffeau, 1994). Nevertheless, only scarce evidence has been presented so far that a toxic compound is extruded from the interior of cells of $S$. cerevisiae to the environment (Breeuwer et al., 1994). The results presented in this work were obtained in the framework of a project in 
which mechanisms of resistance of yeasts to weak acid preservatives are investigated. We observed that induced cells of $S$. cerevisiae released benzoic acid when energy was available and investigated what promotes this event.

\section{METHODS}

Yeast strains and culture conditions. Saccharomyces cerevisiae IGC 3507 was grown aerobically at $30^{\circ} \mathrm{C}$ in an orbital

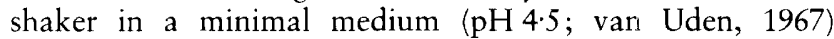
containing $2 \%(\mathrm{w} / \mathrm{v})$ glucose. Cells were adapted to benzoic acid by overnight growth in the presence of $1 \mathrm{mM}$ benzoic acid. Exponential-phase cells $\left(0 \cdot 1-0.5 \mathrm{mg}\right.$ dry wt $\left.\mathrm{ml}^{-1}\right)$ were harvested by centrifugation at $15000 \mathrm{~g}$, washed twice with cold distilled water and resuspended in the same volume of minimal medium without glucose. Cells were kept on ice for no longer than $20 \mathrm{~min}$ before performing the assays. In the experiments to test the effect of cycloheximide, the $\mathrm{pH}$ of the cultures was controlled at 4 , using a pHstat (Radiometer), by the addition of $500 \mathrm{mM} \mathrm{KOH}$.

\section{Assessing extrusion of the acids across the plasma membrane}

Assay 1 . The cell suspension $(50 \mathrm{ml})$ was quickly mixed with 20) $\mu \mathrm{M}\left[7-{ }^{14} \mathrm{C}\right]$ benzoic acid $\left[17.7 \mathrm{mCi} \mathrm{mmol}^{-1}(654.9 \mathrm{MBq}\right.$ $\left.\left.\mathrm{mmol}^{-1}\right)\right], \quad 2 \mu \mathrm{M} \quad\left[3-{ }^{14} \mathrm{C}\right]$ propionic acid $\left[55 \mathrm{mCi} \mathrm{mmol}^{-1}\right.$ $\left.\left(2.03 \mathrm{GBq} \mathrm{mmol}^{-1}\right)\right]$ or $5 \mu \mathrm{M} \quad\left[\right.$ carboxy $\left.{ }^{14} \mathrm{C}\right]$ salicylic acid $\left[11.7 \mathrm{mCi} \mathrm{mmol}^{-1}\left(432.9 \mathrm{MBq} \mathrm{mmol}{ }^{-1}\right)\right]$ and incubated for $1.5 \mathrm{~min}$ at $22^{\circ} \mathrm{C}$. During this incubation, samples $(1 \mathrm{ml})$ were taken, filtered through wet glass microfibre filters (Whatman $\mathrm{GF} / \mathrm{C}$ ) at reduced pressure and washed with $10 \mathrm{ml}$ cold water. A pulse of $2 \%(\mathrm{w} / \mathrm{v})$ glucose was added. Over $90 \mathrm{~min}$, samples $(1 \mathrm{ml})$ were taken, filtered and washed as before. Radioactivity was measured in a liquid scintillation system (Optiphase; LKB). Accumulation ratios were calculated as the ratio between intra- and extracellular concentrations of the label. For the intracellular concentration, intracellular volumes were measured as below. The extracellular concentration was calculated by measuring radioactivity in samples of supernatant.

Assay 2 (to establish the rate of extrusion). The cell suspension $(10 \mathrm{ml})$ was mixed with $\left[7^{14} \mathrm{C}\right]$ benzoic acid as before and incubated for $15 \mathrm{~min}$ at $22^{\circ} \mathrm{C}$. Aliquots $(500 \mu \mathrm{l})$ were transferred to $10 \mathrm{ml}$ conical centrifuge tubes. At time zero, a pulse of $2 \%(\mathrm{w} / \mathrm{v})$ glucose was added. After different incubation times (in the range $0.5-3.5 \mathrm{~min}$ ), the reaction was stopped by the addition of $5 \mathrm{ml}$ cold distilled water. The same filtration procedure described above was performed. Controls were prepared by adding, prior to the glucose addition, $5 \mathrm{ml}$ cold distilled water to the cell suspension. Dry weight was estimated in duplicate by filtering $1 \mathrm{ml}$ suspension through preweighed Millipore membranes $(0.45 \mu \mathrm{m}$ pore) and drying overnight at $80^{\circ} \mathrm{C}$.

Measurement of the initial rate of uptake of $\left[7-{ }^{14} \mathrm{C}\right]$ benzoic acid. The method used has been described previously (Loureiro-Dias \& Peinado, 1984). Cells (1 mg dry wt) were incubated at $22^{\circ} \mathrm{C}$ for $2 \mathrm{~min}$ in $40 \mu \mathrm{l} 50 \mathrm{mM}$ Tris/citrate buffer $(\mathrm{pH} 5)$. A solution of the labelled acid $[10 \mu \mathrm{l} ; 5 \mathrm{mCi}$ $\left.\mathrm{mmol}^{-1}\left(185 \mathrm{MBq} \mathrm{mmol}^{-1}\right)\right]$ was added. The uptake was stopped after $5 \mathrm{~s}$ by the addition of $5 \mathrm{ml}$ ice-cold water. The filters were washed and the radioactivity was measured as described above.

Measurement of intracellular volume. The method described by Rottenberg (1979) was modified using several external markers and ${ }^{3} \mathrm{H}_{2} \mathrm{O}$ to label the total $\mathrm{H}_{2} \mathrm{O}$ volume of the pellet. Cells grown and harvested as described above were resuspended in fresh medium containing $5 \mathrm{mg}$ polyethylene glycol (PEG) $4000 \mathrm{ml}^{-1}\left(1 \mathrm{mg}\right.$ dry wt cells $\left.\mathrm{ml}^{-1}\right)$. Samples $(1 \mathrm{ml})$ were transferred to Eppendorf tubes (in triplicate) and after addition of $2.5 \mu \mathrm{Ci}(92.5 \mathrm{kBq}){ }^{3} \mathrm{H}_{2} \mathrm{O}$ and $0.25 \mu \mathrm{Ci}$ $(9 \cdot 25 \mathrm{kBq})\left[{ }^{14} \mathrm{C}\right] \mathrm{PEG} 4000$, they were incubated for $5 \mathrm{~min}$ at room temperature. Cells were centrifuged at $16000 \mathrm{~g}$ for $10 \mathrm{~min}$. Radioactivity was measured in $20 \mu \mathrm{l}$ supernatant and in the pellet, after removal of the supernatant by suction and cutting the bottom tip of the Eppendorf tube. The pellet was left for $24 \mathrm{~h}$ in scintillation fluid before counting, allowing for the release of radioactivity. In parallel runs, $\left[1,2-{ }^{14} \mathrm{C}\right]$ taurine was used as external marker, instead of $\left[{ }^{14} \mathrm{C}\right] \mathrm{PEG} 4000$, the cells being preincubated with non-labelled taurine $\left(5 \mathrm{mg} \mathrm{ml}^{-1}\right)$. Also, $\left[{ }^{14} \mathrm{C}\right]$ methoxy-inulin was used as an external marker in one experiment. The values obtained with different sets of cells are summarized in Table 1 . Results obtained with PEG 4000 and taurine were submitted to ANOVA. The presence of $1 \mathrm{mM}$ benzoic acid did not significantly affect the results, although significant differences were obtained with the external markers tested. A mean value of $1.42 \mu \mathrm{l}(\mathrm{mg} \text { dry wt })^{-1}$ was used for the calculations of accumulation ratio and intracellular $\mathrm{pH}$.

Intracellular $\mathbf{p H}$. The classical equation derived by Rottenberg (1979) was applied, utilizing $\left[7-{ }^{14} \mathrm{C}\right]$ benzoic acid or [3$\left.{ }^{14} \mathrm{C}\right]$ propionic acid as probes.

Evaluation of $\mathrm{H}^{+}$-pumping activity. $\mathrm{H}^{+}$-pumping activity was evaluated by recording the $\mathrm{pH}$ of unbuffered cell suspensions upon the addition of a pulse of glucose with a combined $\mathrm{pH}$ electrode (C14/02, Phillips) attached to a standard $\mathrm{pH}$ meter (PHM 82; Radiometer) connected to a potentiometer recorder (BBC-GOERZ METRAWATT, SE460). The pH electrode

Table 1. Intracellular volume of $S$. cerevisiae, grown in the absence and in the presence of $1 \mathrm{mM}$ benzoic acid, in mineral medium

Initial $\mathrm{pH}$ was 4.5 and it decreased to 3.5 when the cells were harvested. Measurements were performed with different external markers.

\begin{tabular}{|lcc|}
\hline External marker & \multicolumn{2}{c|}{ Intracellular volume $\left[\boldsymbol{\mu l}(\mathbf{m g} \text { dry wt })^{-1}\right]$} \\
\cline { 2 - 3 } & No addition & Benzoic acid $(\mathbf{1 ~ m M})$ \\
\hline PEG 4000 & $1 \cdot 50 \pm 0 \cdot 19(n=5)$ & $1 \cdot 72 \pm 0 \cdot 48(n=4)$ \\
Taurine & $1 \cdot 24 \pm 0 \cdot 13(n=5)$ & $1 \cdot 22 \pm 0 \cdot 19(n=5)$ \\
Methoxy-inulin & $1 \cdot 8(n=1)$ & $1 \cdot 9(n=1)$ \\
\hline
\end{tabular}


was immersed in a water-jacketed cell supplied with magnetic stirring. First, $3.5 \mathrm{ml}$ water and $0.5 \mathrm{ml}$ cell suspension were successively added and a base line was obtained in the recorder. The addition of $2 \%(\mathrm{w} / \mathrm{v})$ glucose initiated the activity of the $\mathrm{H}^{+}$-pump, observed by the acidification of the extracellular environment. Calibrations were performed with $10 \mathrm{mM} \mathrm{HCl}$.

Reproducibility of the results. All experiments were performed at least three times. Results of typical experiments are presented.

Materials. $\left[7-{ }^{14} \mathrm{C}\right]$ Benzoic acid, $\left[1,2-{ }^{14} \mathrm{C}\right]$ taurine and $\left[{ }^{14} \mathrm{C}\right]-$ methoxy-inulin were from NEN, $\left[3-{ }^{14} \mathrm{C}\right]$ propionic acid, ${ }^{3} \mathrm{H}_{2} \mathrm{O}$ and $\left[{ }^{14} \mathrm{C}\right] \mathrm{PEG} 4000$ were from Amersham, and [carboxy$\left.{ }^{14} \mathrm{C}\right]$ salicylic acid was from Sigma.

\section{RESULTS}

\section{Uptake and release of benzoic acid by S. cerevisiae}

When $\left[{ }^{14} \mathrm{C}\right]$ benzoic acid was added to a cell suspension of $S$. cerevisiae, the label entered the cells and accumulated, as expected. In about $15 \mathrm{~min}$, a steady state was reached. In Fig. 1(a), the cells were initially in the absence of an energy source, and the addition of a pulse of glucose resulted in a short transient decrease, followed by a steady increase, of benzoic acid accumulation. These alterations in the level of accumulation can be explained by changes in intracellular $\mathrm{pH}$ associated with the metabolism of glucose and the activation of the plasma membrane ATPase. First, a slight acidification occurs due to phosphorylation of glucose, which is overcome when ATP is available and protons are pumped out (Ramos et al., 1989). Intracellular $\mathrm{pH}$ values calculated from the steady state accumulation ratios before and after the addition of glucose were 6.5 and $6 \cdot 7$, respectively. The shape of the curve is in good agreement with results obtained for intracellular $\mathrm{pH}$ calculated from the chemical shift of ${ }^{31} \mathrm{P}$ by NMR, using the same strain (Loureiro-Dias \& Santos, 1990). The results of a parallel experiment run with cells grown in the presence of $1 \mathrm{mM}$ benzoic acid are presented in Fig. 1 (b). In this case, the initial steady state was reached at a lower accumulation ratio of the label as expected, since the intracellular $\mathrm{pH}$ is lower when the cells are grown in the presence of a weak acid (Pampulha \& Loureiro-Dias, 1989). When glucose was added, a massive export of the label was observed. If, as before, intracellular $\mathrm{pH}$ was calculated from the final steady state obtained, a value of 4.5 would result, which may be considered an indication that benzoic acid is no longer in equilibrium, across the plasma membrane. The process was energy-dependent and did not depend merely on the presence of a sugar: addition of 2-deoxyD-glucose, a non-metabolizable analogue of glucose, did not affect the level of the label in the cells, while a pulse of $2 \%(\mathrm{v} / \mathrm{v})$ ethanol to energy-depleted cells (pregrown on ethanol) elicited the release of benzoic acid (results not shown).

Working with small volumes of cell suspension (assay 2, in Methods), it was possible to control more precisely the time of incubation with glucose, by stopping the

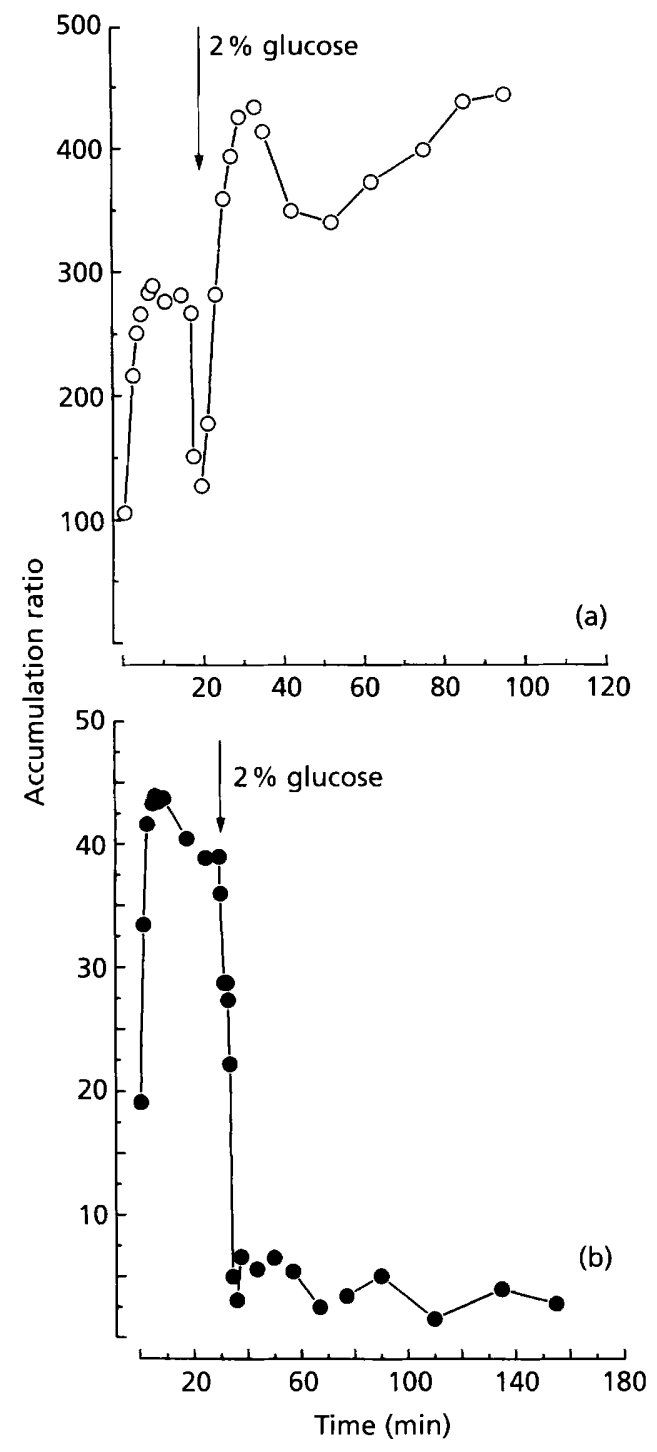

Fig. 1. Effect of the addition of a pulse of $2 \%(\mathrm{w} / \mathrm{v})$ glucose to cells of $S$. cerevisiae preloaded with $\left[{ }^{14} \mathrm{C}\right]$ benzoic acid. (a) Cells grown without benzoic acid; (b) cells grown in the presence of $1 \mathrm{mM}$ benzoic acid.

reaction by dilution with ice-cold water. A detailed evaluation of the time-course of the release is indicated in Fig. 2. Release of benzoic acid started about $1.5 \mathrm{~min}$ after glucose addition.

Cells able to extrude benzoic acid also extruded salicylic acid under the same assay conditions (not shown).

\section{Regulation of the mechanism of extrusion of benzoic acid}

As the results in Fig. 1 indicate, cells must be previously grown in the presence of benzoic acid for the expulsion to occur. In order to evaluate the time-course of the process of induction and the role of protein synthesis in the emergence of the phenomenon, we performed the 


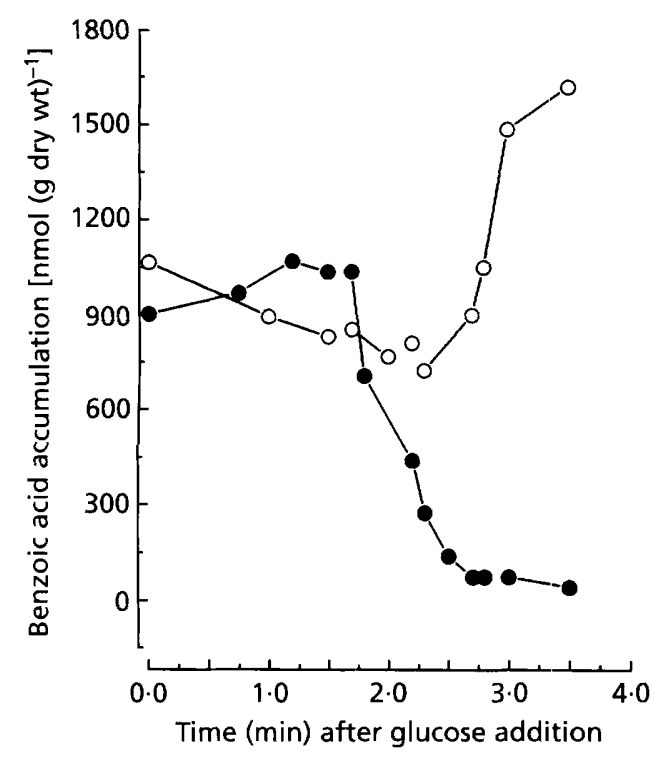

Fig. 2. Time-course variation of benzoic acid accumulation after the addition of a pulse of $2 \%(\mathrm{w} / \mathrm{v})$ glucose to cells of $S$. cerevisiae preloaded with $\left[{ }^{14} \mathrm{C}\right]$ benzoic acid. $O$, Cells grown without benzoic acid; 9 , cells grown in the presence of $1 \mathrm{mM}$ benzoic acid.

Table 2. Substrates tested for their ability to induce the mechanism of extrusion of benzoic acid in 5 . cerevisiae when present in the growth medium

Extrusion was triggered by the addition of a pulse of glucose to cells preloaded with $\left[{ }^{14} \mathrm{C}\right]$ benzoic acid.

\begin{tabular}{|lc|}
\hline Substrate & $\begin{array}{c}\text { Extrusion of } \\
\text { benzoic acid }\end{array}$ \\
\hline None & - \\
Benzoic acid $(1 \mathrm{mM})$ & + \\
Sorbic acid $(1 \mathrm{mM})$ & + \\
Hexanoic acid $(1 \mathrm{mM})$ & + \\
Octanoic acid $(1 \mathrm{mM})$ & + \\
Salicylic acid $(1 \mathrm{mM})$ & + \\
Butyric acid $(1 \mathrm{mM}\rangle$ & + \\
Propionic acid $(1 \mathrm{mM})$ & + \\
Ethanol $(1.2 \mathrm{M})$ & - \\
Acetic acid $(10 \mathrm{mM})$ & - \\
\hline
\end{tabular}

following experiment. A culture grown in the absence of benzoic acid was divided into two aliquots. Benzoic acid $(1 \mathrm{mM})$ was added to both and cycloheximide $(10 \mu \mathrm{g}$ $\mathrm{ml}^{-1}$ ) was added to one of them. Samples were taken every $8 \mathrm{~h}$ and the cells were tested for the ability to extrude benzoic acid. In the culture without cycloheximide, extrusion became apparent after $28 \mathrm{~h}$. The presence of cycloheximide in the other culture prevented emergence of the extrusion, suggesting that de novo protein synthesis is involved. This experiment was performed at $\mathrm{pH} \mathrm{4,} \mathrm{and} \mathrm{this} \mathrm{value} \mathrm{was} \mathrm{kept} \mathrm{constant}$ with a pHstat. This was important to avoid any different

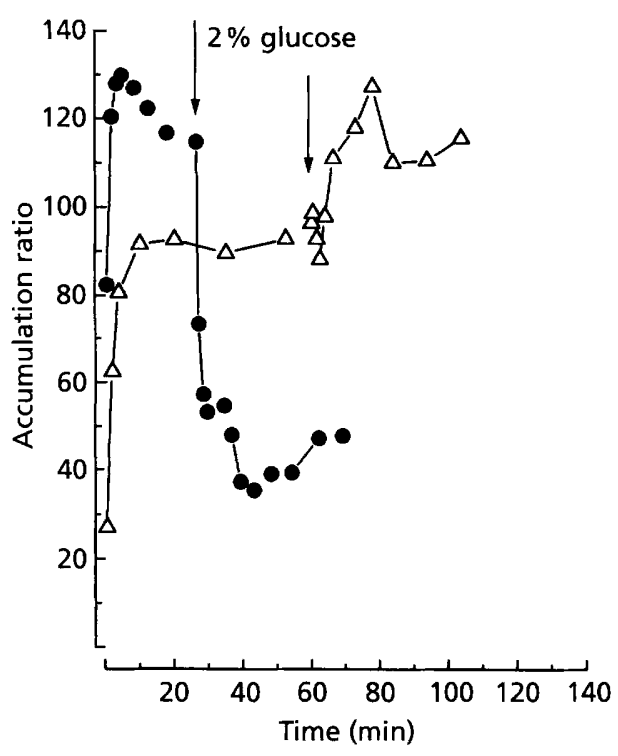

Fig. 3. Variation of the accumulation ratios after the addition of a pulse of $2 \%(\mathrm{w} / \mathrm{v})$ glucose to cells of $S$. cerevisiae preloaded with $\left[{ }^{14} \mathrm{C}\right]$ benzoic acid $(O)$ or with $1 \mathrm{mM}$ propionic acid $(\triangle)$. Cells were grown in the presence of $1 \mathrm{mM}$ propionic acid.

levels of toxicity in both cultures that could arise, since only in the absence of cycloheximide could the cells grow and maintain anabolic activities.

Several compounds were tested as possible inducers when present in the growth medium (Table 2). Expulsion of benzoic acid occurred in all cases except with acetic acid or ethanol. Since propionic acid was an inducer of the benzoic acid release, it was checked whether propionic acid would also be extruded by the cells. The results are shown in Fig. 3: cells grown in the presence of propionic acid extruded benzoic acid but not propionic acid. This compound acted as an inducer but not as a substrate.

\section{Action of inhibitors}

Diethylstilbestrol (DES), an inhibitor of the plasma membrane ATPase (Serrano, 1980), completely prevented the expulsion of benzoic acid at a concentration of $0.2 \mathrm{mM}$, while a concentration of $1 \mathrm{mM}$ DES was necessary to inhibit the $\mathrm{H}^{+}$-pumping activity. A curious observation was that a concentration of $0.2 \mathrm{mM}$ was enough to inhibit the $\mathrm{H}^{+}$-pumping activity of cells nonadapted to benzoic acid.

Reserpine, a known inhibitor of pleiotropic drug resistance (Allen et al., 1990), did not affect the process of benzoic acid expulsion.

\section{Mechanism of influx of benzoic acid}

Although it is generally accepted that benzoic acid crosses membranes by simple diffusion through the lipids, the presence of a carrier responsible for extrusion in the plasma membrane might interfere in the uptake of the acid. We established the kinetics of initial uptake of 


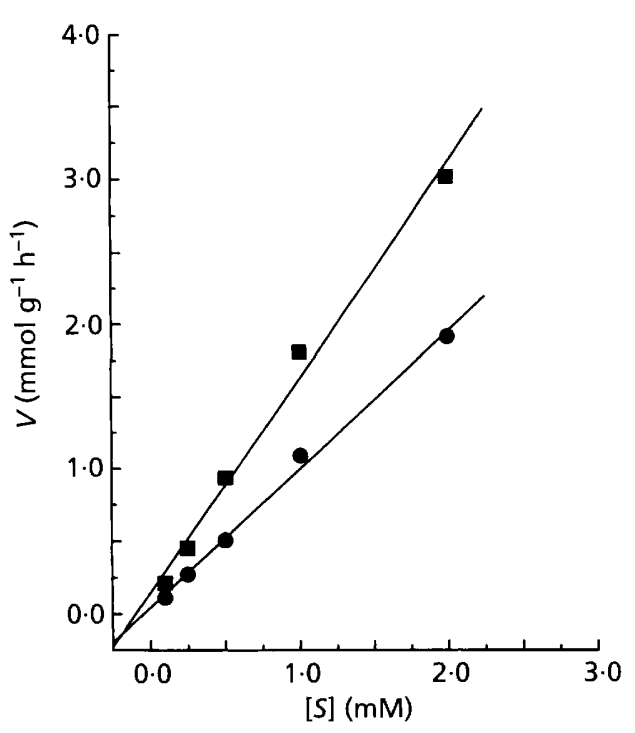

Fig. 4. Effect of ethanol on the initial uptake rate of benzoic acid in cells of $S$. cerevisiae grown in the presence of $1 \mathrm{mM}$ benzoic acid. 0 , No ethanol added; $\square, 4 \%(\mathrm{w} / \mathrm{v})$ ethanol in the assay.

$\left[{ }^{14} \mathrm{C}\right]$ benzoic acid and observed that in cells grown in either the absence or the presence of benzoic acid kinetics were linear and the calculated diffusion coefficients were, respectively, 1.49 and $0.94 \mathrm{ml} \mathrm{mg}^{-1} \mathrm{~h}^{-1}$. In adapted cells, we also measured the uptake of $\left[{ }^{14} \mathrm{C}\right]$ benzoic acid in the presence of several concentrations of non-labelled benzoic acid. The radioactivity trapped inside the cells in the transport assay was proportional to the concentration of $\left[{ }^{14} \mathrm{C}\right]$ benzoic acid and independent of the concentration of the non-labelled benzoic acid. This is a good indication that this acid crossed the membrane by a non-mediated mechanism, since in a mediated process the non-labelled acid should behave as a competitive inhibitor of the labelled one. In the same cells, ethanol $(4 \%, w / v)$ present in the transport assay stimulated the uptake of benzoic acid (Fig. 4), confirming that the uptake occurred through the lipid bilayer and did not involve membrane proteins (van Uden, 1989).

\section{DISCUSSION}

The data presented show that $S$. cerevisiae can extrude benzoic acid by an energy-dependent process. The fact that ethanol, but not 2-deoxy-D-glucose, elicited the process is a good indication that energy is really involved. However, the time span between the addition of the energy source and the beginning of the process suggests that metabolism has to occur and eventually ATP has to be formed. Inhibition by DES suggests that a specific ATPase may be involved in the extrusion of benzoic acid.

In order to calculate accumulation ratios and intracellular $\mathrm{pH}$, we made determinations of intracellular volume following conventional methodologies. According to our results, the intracellular volume was not affected by the presence of $1 \mathrm{mM}$ benzoic acid in the culture. In previous work (Cole \& Keenan, 1987), an important decrease in the protoplast volume of $Z$. bailii, correlated with growth rate, had been reported for cells grown in the presence of sorbic and benzoic acids. Taking into account this discrepancy, we took particular care in these determinations. Besides the usual external marker for yeasts, methoxy-inulin, we used the neutral molecule PEG 4000 and taurine. By using these labelled markers, in the presence of rather high concentrations of the non-labelled forms we expected to minimize cellular binding, as has been successfully used with bacteria (Salema et al., 1996). Warth (1989) states that growth of $Z$. bailii in $2 \mathrm{mM}$ benzoic acid reduces cytoplasmic volume by less than $5 \%$ and presents data indicating that, in general, more resistant species of yeasts have higher cytoplasmic volumes, calculated from microscopic observations. It is difficult to reconcile this observation with the strong reduction of protoplasmic volume reported by Cole \& Keenan (1987) when Z. bailii is adapted to sorbic or benzoic acid.

We confirmed that even under conditions where extrusion was present, benzoic acid entered the cell by simple diffusion. Good indications came from the observation that the uptake of the labelled acid did not depend on the specific activity, confirming that the kinetics were linear, and from the stimulation of uptake observed in the presence of ethanol. This behaviour has been attributed to disorder in the lipid bilayer created by molecules of ethanol. This effect in the membrane inhibits mediated transport (van Uden, 1989) and stimulates passive diffusion (Leão \& van Uden, 1984; van Uden, 1989). The fact that a saturation component in the kinetics uptake was not found indicates that the mechanism of extrusion is unidirectional, at least under the conditions tested.

Several weak acids, when present in the growth medium, induced the mechanism to extrude benzoic acid. It is interesting that acetic acid did not behave as such, suggesting that the mechanism of induction is not mediated by the intracellular acidification induced by the presence of the acids. Acetic acid did not act as an inducer, probably because it is not recognized by the cell as a foreign compound, since it is a common metabolic end-product. The case of propionic acid, able to induce and not utilize this mechanism, should be noted. The observation that benzoic acid was extruded by cells of $S$. cerevisiae was made when we were testing probes for evaluation of intracellular $\mathrm{pH}$ (radioactive benzoic and propionic acids) and comparing the results with values obtained by ${ }^{31} \mathrm{P}-\mathrm{NMR}$. While the values obtained with propionic acid were in good agreement with those obtained for cytoplasmic $\mathrm{pH}$ by ${ }^{31} \mathrm{P}-\mathrm{NMR}$, those obtained with benzoic acid agreed with those obtained by other methods only when cells had been grown in the absence of a weak acid. When the cells had been previously incubated (or grown) with a weak acid, the results for intracellular $\mathrm{pH}$ obtained with benzoic acid 
were very low. This was an indication that the acid was not in equilibrium and that the anion was being extruded. This result was in agreement with previous observations in continuous culture (Verduyn et al., 1992) and led us to search for conditions under which the expulsion could be observed. The difference in behaviour observed with benzoic and propionic acid is important, because it validates propionic acid as a good probe to measure intracellular $\mathrm{pH}$ even when the cells were grown in the presence of a weak acid.

W'arth (1977) presented evidence in favour of benzoic acid being extruded by pre-adapted cells of $Z$. bailii. Cole \& Keenan (1987) interpreted theirs and Warth's results, assuming that the lower level of benzoic acid inside the cells, observed upon the addition of a pulse of sugar, could result from a decrease in intracellular $\mathrm{pH}$, which they observed upon the addition of fructose to cells of $Z$. bailii starved for $20 \mathrm{~h}$ at $\mathrm{pH} 4 \cdot 5$. In this case it is not proven that the cells are really metabolizing the sugar. Our data, however, present stronger evidence in favour of real expulsion (in S. cerevisiae) : it is not a simple re-equilibration under a new intracellular $\mathrm{pH}$, which would also certainly occur with 2-deoxy-Dglucose (which is phosphorylated) and should also occur with propionic acid as substrate. Some preliminary results indicate that the observations we report in this work for S. cerevisiae do also occur in Z. bailii.

The hypothesis that the yeast would modify or metabolize benzoic acid, which could justify the loss of the label, was considered. However, the confirmation that benzoic acid was not consumed upon glucose addition in the time-course of extrusion was obtained by HPLC (results not shown).

We also considered the hypothesis that a mechanism of pleiotropic drug resistance was involved in the benzoic acid extrusion. Mutants affected in pleiotropic drug resistance (Balzi \& Goffeau, 1994) were tested for their ability to extrude benzoic acid. Both DRI9-T8 (a drug resistant mutant) and D1-3/3 (a hypersensitive mutant) behaved as the parental strain. We also tested as possible inducers some compounds whose toxicity depends on activity of pleiotropic drug resistance mechanisms (phenanthroline, antimycin $\mathrm{A}$ and oligomycin). None of these compounds elicited induction of the benzoic acid extrusion mechanism. These are good indications that a different mechanism is involved in this case.

The physiological role of the mechanism of extrusion in the global resistance to weak acids has to be further investigated. It has been claimed (Cole \& Keenan, 1987) that such a mechanism would be useless or even futile since the cells are continuously being invaded by nondissociated molecules of the acid. However, it should be taken into consideration that in a steady state situation, the intracellular concentration of the acid, even if the extrusion mechanism does exist, may be quite high, resulting in a low driving force and a reduced diffusion. The efficiency of the extrusion mechanism will also depend on the ability of the yeasts to restrict the access of the toxic acids, by changing the composition of the membrane and decreasing the diffusion coefficients. We are currently studying these mechanisms.

Our work clearly shows that the mechanism of benzoic acid extrusion is inductive. Evidence for the strong induction of a plasma membrane protein $(150 \mathrm{kDa})$ by sorbate in $S$. cerevisiae and $Z$. bailii has recently been reported (Piper et al., 1995). It is possible that this protein is involved in the extrusion of this type of compound.

\section{ACKNOWLEDGEMENTS}

This work was supported by the European Union (AIR-CT93-830). We thank Dr A. Goffeau from the Universite Catholique de Louvain for providing the mutants affected in pleiotropic drug resistance.

\section{REFERENCES}

Allen, C. N., Harpur, E. S., Gray, T. J. B., Simmons, N. L. \& Hirst, B. H. (1990). Efflux of bis-carboxylethyl-carboxyfluorescein (BCECF) by a novel ATP-dependent transport mechanism in epithelial cells. Biochem Biophys Res Commun 172, 262-267.

Balzi, E. \& Goffeau, A. (1994). Genetics and biochemistry of yeast multidrug resistance. Biochim Biophys Acta 1187, 152-162.

Breeuwer, P., Drocourt, J.-L., Rombouts, F. M. \& Abee, T. (1994). Energy-dependent, carrier-mediated extrusion of carboxyfluorescein from Saccharomyces cerevisiae allows rapid assessment of cell viability by flow cytometry. Appl Environ Microbiol 60, 1467-1472.

Cole, M. B. \& Keenan, M. H. J. (1987). Effects of weak acids and external $\mathrm{pH}$ on the intracellular $\mathrm{pH}$ of Zygosaccharomyces bailii, and its implications in weak-acid resistance. Yeast 3, 23-32.

Decottignies, A., Kolaczkowski, M., Balzi, E. \& Goffeau, A. (1994). Solubilization and characterization of the overexpressed PDR5 multidrug resistance nucleotide triphosphatase of yeast. J Biol Chem 269, 12797-12803.

Krebs, H. A., Wiggins, D., Stubbs, M., Sols, A. \& Bedoya, F. (1983). Studies on the mechanism of the antifungal action of benzoate. Biochem J 214, 657-663.

Leão, C. \& van Uden, N. (1984). Effects of ethanol and other alkanols on passive proton influx in the yeast Saccharomyces cerevisiae. Biochim Biophys Acta 774, 43-48.

Loureiro-Dias, M. C. \& Peinado, J. M. (1984). Transport of maltose in Saccharomyces cerevisiae. Effect of $\mathrm{pH}$ and potassium ions. Biochem J 222, 293-298.

Loureiro-Dias, M. C. \& Santos, H. (1990). Effects of ethanol on Saccharomyces cerevisiae as monitored by in vivo ${ }^{31} \mathrm{P}$ and ${ }^{13} \mathrm{C}$ nuclear magnetic resonance. Arch Microbiol 153, 384-391.

Pampulha, M. E. \& Loureiro-Dias, M. C. (1989). Combined effect of acetic acid, $\mathrm{pH}$ and ethanol on intracellular $\mathrm{pH}$ of fermenting yeast. Appl Microbiol Biotechnol 31, 547-550.

Pampulha, M. E. \& Loureiro-Dias, M. C. (1990). Activity of glycolytic enzymes of Saccharomyces cerevisiae in the presence of acetic acid. Appl Microbiol Biotechnol 34, 375-380.

Piper, P. W., Braley, R., Calderon, C. O., Kong, T., Seymour, I. \& Talreja, K. (1995). Adaptation of yeast to weak organic acids; a specific stress response. Yeast 11, S585.

Ramos, S., Balbín, M., Raposo, M., Valle, E. \& Pardo, L. A. (1989). The mechanism of intracellular acidification induced by glucose in Saccharomyces cerevisiae. J Gen Microbiol 135, 2413-2422. 
Rottenberg, H. (1979). The measurement of membrane potential and $\Delta \mathrm{pH}$ in cells, organelles and vesicles. Methods Enzymol 55, 547-569.

Salema, M., Lolkema, J. S., San Romão, M. V. \& Loureiro-Dias, M. C. (1996). The proton motive force generated in Leuconostoc oenos by L-malate fermentation. J Bacteriol 178, 3127-3132.

Serrano, R. (1980). Effect of ATPase inhibitors on the proton pump of respiratory-deficient yeast. Eur J Biochem 105, 419-424.

Thomas, D. S. \& Davenport, R. R. (1985). Zygosaccharomyces bailii - a profile of characteristics and spoilage activities. Food Microbiol 2, 157-169.

van Uden, N. (1967). Transport-limited fermentation and growth of Saccharomyces cerevisiae and its competitive inhibition. Arch Mikrobiol 58, 155-168.

van Uden, N. (1989). Effects of alcohols on membrane transport in yeasts. In Alcohol Toxicity in Yeasts and Bacteria, pp. 135-146. Edited by N. van Uden. Boca Raton, FL: CRC Press.
Verduyn, C., Postma, E., Scheffers, W. A. \& van Dijken, J. P. (1992). Effect of benzoic acid on metabolic fluxes in yeasts: a continuous-culture study on the regulation of respiration and alcoholic fermentation. Yeast 8, 501-517.

Warth, A. D. (1977). Mechanism of resistance of Saccharomyces bailii to benzoic, sorbic and other weak acids used as food preservatives. J Appl Bacteriol 43, 215-230.

Warth, A. D. (1988). Effect of benzoic acid on growth yield of yeasts differing in their resistance to preservatives. Appl Environ Microbiol 54, 2091-2095.

Warth, A. D. (1989). Relationship among cell size, membrane permeability, and preservative resistance in yeast species. Appl Environ Microbiol 55, 2995-2999.

Received 14 October 1996; revised 9 January 1997; accepted 6 February 1997. 